\title{
Transformasi Fungsi Alat Batu Semu Situs Gunungwingko
}

\section{Goenadi Nitihaminoto}

Keywords: lithic, stone tools, settlement, bantul, prehistory, data transformation

\section{How to Cite:}

Nitihaminoto, G. (1995). Transformasi Fungsi Alat Batu Semu Situs Gunungwingko. Berkala Arkeologi, 15(2), 1-9. https://doi.org/10.30883/jba.v15i2.656

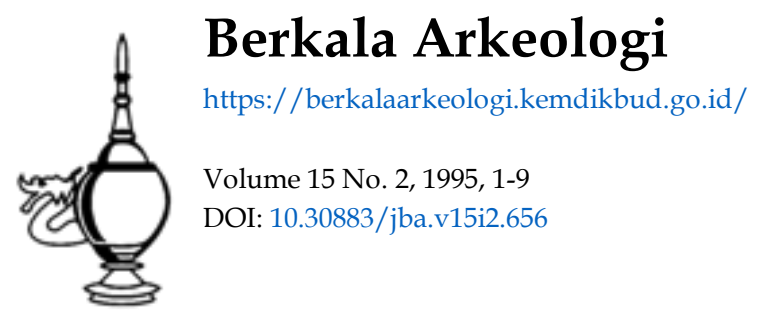

\section{(c) (1) (9)(2)}

This work is licensed under a Creative Commons Attribution-NonCommercial-ShareAlike 4.0 International License. 


\title{
TRANSFORMASI FUNGSI ALAT BATU SEMU SITUS GUNUNOWINGKO
}

\author{
Goenadi Nitihaminoto \\ (Balai Arkeologi Yogyakarta)
}

\section{Pendahuluan}

Dalam kehidupan sehari-hari, manusia tidak dapat dipisahkan dar! peralatan yang digunakan sebagai alat untuk mencapai kenyamanan hidup. Peralatan itu mempunyai berbagai fungsi antara lain sebagai alat produksi, ekonomi, senjata atau untuk membela diri, mempercantik diri, dan alat yang digunakan untuk kepentingan upacara. Fungsi alat-alat tersebut berkaitan dengan bahan pembuatnya sehingga jenis bahan tertentu berkaitan dengan fungsi alat tertentu pula, meskipun tidak selamanmya demikian. Hubungan antara fungsi dan bahan pembuatan alat tersebut dapat dicontohkan sebagai berikut Alat-alat produksi dan ekonomi dibuat hampir dari berbagai jenis bahan, alat untuk membela diri dibuat dari segala jenis bahan, alat mempercantik diri dibuat dari jenis batuan tertentu dan logam khususnya bukan besi, dan alat untuk kepentingan upacara dibuat dari segala jenis bahan, yang sebelumnya digunakan sebagai alat praktis

Berdasarkan bahan pembuatannya, peralatan (artefak) dibuat dari beberapa jenis antara lain tanah liat, kaca, kuningan, besi, emas, perak, batu, kayu, serabut, benang, kulit binatang, tanduk, tulang, gading, dan material-material lain (Hodges, 1981:19--166). Batu yang digunakan sebagai bahan pembuatan artefak terdiri atas beberapa jenis, antara lain batuan yang mempunyai kekerasan tinggi dan batu yang tingkat kekerasannya rendah jarang digunakan sebagai bahan pembuatan alat Berdasarkan teknologinya, terdapat dua jenis alat yaitu alat yang dibuat deriyan melalui proses teknologi dan alat yang dibuat tanpa melalui proses terknologi. Alat yang dibuat melalui tahapan teknologi, terdiri atas perencanaan (gagasan), aktivitas (proses pembuatan), dan hasil aktivitas yang berupa produk yang dimaksudkan. Sementara itu, alat yang diperoleh tanpa proses teknologi tertentu, pada umumnya diambil dari benda-benda alam yang ada di sekitarnya yang kemudian langsung digunakan sebagai alat, misalnya batu yang digunakan sebagai alat pelempar, penggosok, peloandas, dan pemukul. Alat semacam ini disebut pseudo artifact atau alat semu.

Dalam pengambilan benda alam yang digunakan sebagai artefak semu tersebut terdiri atas dua macam yaitu yang berasal dari benda 
alam dan berasal dari artefak yang sudah tidak terpakai lagi, kemudian setelah dimodifikasi atau tanpa modifikasi difungsikan kembali sebagai artefak. Berdasarkan fungsinya, alat-alat yang digunakan untuk kepentingan sehari-hari dapat digunakan sebagai bekal kubur atau untuk kepentingan upacara lainnya, sehingga terdapat transformansi fungsi, dari fungsi praktis ke fungsi seremonial. Dalam hubungan ini, maka tulisan ini akan mengkaji transformasi fungsi artefak semu, khususnya yang dibuat dari bahan batu di Situs Gunungwingko. Situs ini merupakan situs permukiman pantai yang terletak di pantai selatan daerah Kabupaten Bantul.

Usaha untuk mengungkapkan transformasi fungsi artefak tersebut diperlukan dua cara, yaitu pengamatan teknologis dan kontekstual. Pengamatan teknologis, berlaku khusus untuk alat yang pembuatannya melalui proses teknologi tertentu, sedangkan pengamatan pada bekas pemakaian umumnya dilakukan pada artefak semu.

Alat batu Situs Gunungwingko terdiri atas dua macam yaitu alat batu semu dan alat batu murni. Kedua jenis alat itu ditemukan dengan konteks temuan lain yaitu berupa rangka manusia. Dalam hubungannya dengan konteks temuan itu, maka fungsi kedua jenis alat batu tersebut diperkirakan sebagai fungsi pelengkap upacara atau sebagai benda upacara yang sebelumnya pernah berfungsi sebagai alat praktis. Sebagai alat praktis, alat batu semu Gunungwingko ditandai oleh beberapa bekas pemakaian seperti digunakan sebagai alat pemukul, alat pelandas, dan sebagai alat penggosok. Sementara itu, alat batu murni terdiri atas bentuk calon beliung persegi, yang secara praktis belum digunakan.

\section{Alat Batu Semu Situs Gunungwingko}

Telah diuraikan sebelumnya, alat batu semu Gunungwingko dibuat dari batu andesit dan granit yang sebagian besar berasal dari batu alam. Berdasarkan pembundaran yang terdapat pada bahan alat tersebut dapat dikelompokkan menjadi dua yaitu berasal dari sungai dan laut. Bahan baku yang berasal dari sungai ditandai dengan bentuk bulat lonjong, sedangkan bahan batu yang berasal dari laut ditandai dengan bentuk bulat, oval, dan segi empat yang pada umumnya pipih.

Daerah asal alat batu tersebut memang didukung oleh lingkung. an di sekitarnya, karena Situs Gunungwingko terletak pada dua deret bukit pasir yang dibatasi oleh Samudera Indonesia di sebelah selatan dan diapit oleh dua batang sungai, yaitu Sungai Opak di timur dan Sungai Bedog di barat. Sumber bahan primer, baik andesit maupun granit berasal dari Gunungapi Merapi yang kemudian dibawa oleh ke dua batang sungai tersebut ke laut Dalam proses transportasi ini 
sebagian masuk ke dalam laut yang kemudian dilemparkan kembali ke darat, sementara itu sebagian terendapkan di tebing atau dasar sungai sehingga memberikan bentuk yang berbeda.

Sementara itu, yang dimasudkan dengan alat batu semu dalam tulisan ini ialah alat batu yang bahannya berasal dari batu yang biasa terdapat di pantai dam sungai dan alat batu lain yang telah rusak. Alat batu semu yang bahannya dari pantai dan sungai diambil langsung dari lingkungan itu kemudian digunakan sebagai alat, sedangkan alat batu semu lainnya berasal dari pecahan-pecahan yang menunjukkan adanya pengerjaan yang halus. Pecahan alat batu itu berasal dari alat batu murni yang kemudian digunakan sebagai alat lagi.

Alat batu semu Situs Gunungwingko secara fungsional terdiri atas tiga kelompok yaitu penggosok, pelandas, dan pemukul. Masing-masing jenis tersebut mempunyai ciri-ciri sendiri, sehingga membedakan fungsi yang satu dengan fungsi alat batu lainnya. Pada umumnya, bahan yang digunakan adalah andesit dan granit yang berasal dari batu sungai dan yang berasal dari laut. Temuan alat batu ini ditemukan dari berbagai kedalaman dan lapisan budaya. Bentuk artefak itu secara umum sesuai dengan bentuk bahan aslinya sehingga tidak beraturan Alat-alat batu semu tersebut pada mulanya diidentifikasikan sebagai batu alam biasa, tetapi kemudian setelah diamati ciri-ciri bekas pemakaian dapat diidentifikasikan sebagai alat batu semu yang berfungsi sebagai alat penggosok, pelandas, dan pemukul.

\subsection{Alat Penggosok}

Alat ini ditandai oleh beberapa hal yaitu bahan, bentuk, ukuran, bekas pemakaian, kedalaman, dan relasinya dengan temuan lain. Bahan alat ini dibuat dari batu andesit dan granit, batuan andesit lebih banyak daripada batu granit. Bentuknya tidak beraturan dan pada umumnya mendekati bentuk bulattelur, segitiga, trapesium, dan segiempat. Bentuk-bentuk itu berasal dari bentuk batu alam dan karena pemakaian itu maka bentuknya sedikit mengalami perubahan sehingga mendekati bentuk-bentuk geometris. Alat batu penggosok yang paling kecil berukuran panjang $4 \mathrm{~cm}$, lebar $4 \mathrm{~cm}$, dan tebal 1,5 $\mathrm{cm}$, sedangkan alat batu penggsosok paling besar berukuran panjang $6 \mathrm{~cm}$, lebar $4 \mathrm{~cm}$, dan tebal $2 \mathrm{~cm}$.

Bekas-bekas pemakaian yang terdapat pada batu tersebut merupakan ciri utama yang menentukan bahwa batu itu adalah alat. Bekas-bekas pemakaian berupa bekas penggosokan yang dapat dilihat pada ke dua bidang atau satu bidang bidang lebar, dan bekas pemakaian lain terdapat pada sebuah sisi tebal atau pada ke dua 
sisinya. Berdasarkan bekas pemakaian itu dapat dikenali benda yang digosok merupakan benda keras yang halus, sehingga meninggalkan bekas gosokan yang mengkilat dan benda benda keras yang kasar, sehingga meninggaikan bekas gosokan yang kasar pula. Bekas pemakaian yang meninggalkan bekas halus pada umumnya terdapat pada satu sisi tebal, sementara itu bekas penggosokan yang meninggalkan bekas kasar terdapat pada bidang lebar.

Batu penggosok ini ditemukan pada kedalaman yang bervariasi, yaitu mulai $30 \mathrm{~cm}, 60--80 \mathrm{~cm}, 120-130 \mathrm{~cm}$, dan $150--160 \mathrm{~cm}$ Kedalaman-kedalaman itu apabila disesuaikan dengan lapisan budaya, maka temuan alat batu semu tersebut berada lapisan budaya.4, lapisan budaya-3, dan lapisan budaya-2. Telah diketahui lapisan budaya adalah lapisan tanah yang terbentuk oleh aktivitas manusia sehingga mengandung segala jenis benda yang pernah digunakan dalam kehidupan mereka masa lampau. Benda-benda yang digunakan dalam aktivitas manusia tersebut lama kelamaan tertimbun oleh endapan yang terjadi di suatu daerah sehingga apabila peristiwa sedimentasi itu terjadi berulang-ulang akan membentuk beberapa lapis lapisan budaya.

Alat-alat batu di lapisan budaya berkorelasi dengan gerabah, manik-manik, artefak logam, tulang manusia, tulang hewan, dan arang, sementara itu di lapisan budaya-3 berkorelasi dengan gerabah, keramik asing, manik-manik, artefak logam, tulang manusia, tulang hewan, dan arang, dan pada lapisan budaya-2 berkorelasi dengan gerabah, manik-manik, artefak logam, dan temuan bukan artefak seperti rangka manusia, tulang hewan, arang, dan lapies."

\subsection{Alat Pelandas (Anvin}

Dalam menentukan alat batu ini didasari oleh beberapa hal seperti halnya alat penggosok. Bahan pada umumnya dibuat dari granit yang berbentuk relatif bulat atau bulattelur pipih dan segiempat, sehingga

${ }^{3}$ Lapies, bahasa Perancis yang dalam bahasa Jerman disebut karren. yaitu permukaan batu kapur yang beralur sebagai akbat dari kandungan karbon dioksida yang terdapat dalam air hujan yang kemudian membentuk lubang sampai ke dalam batuan tersebut yang biasamya terdapat pada daerah karst (W.G.Moore, 1981:130; J.B. Whittow, 1984: 302). Lubang-lubang itu akhimya memyebabkan batuan itu pecah sebagian kedalam bentuk yang tiak teratur dengan ukuran yang bervariasi. Pada umumnya, lapies yang berukuran kecil sukar dibedakan dari terak besi (iron slag) karena mempunyai kenampaan sama. Untuk membedakan harus melalui ujl laboratorium atau berdasarkan konteks temuan dan lingkungan. 
dapat memberikan petunjuk bahwa batu ini berasal dari hasil aktivitas gelombang. Batu pelandas yang berbentuk bulat berukuran $9,5 \times 8,5 \times$ $1,5 \mathrm{~cm}$, adapun alat pelandas yang berbentuk segiempat berukuran $9 \times$ $9 \times 2 \mathrm{~cm}$

Bekas-bekas pemakaian pada alat ini sukar dikenali, karena hampir tidak meninggalkan bekas pemakaian. Oleh karena itu, dałam menentukan fungsi alat ini perlu dibandingkan dengan alat lain yang serupa, yaitu bentuk alat dalam pembuatan gerabah yang digunakan sebagai pelandas dalam proses pembuatan gerabah. Kecurigaan kuat. bahwa batu ini sebagai alat, adalah lokasi temuan yang secara geografis sebagai akibat tenaga angin, sehingga membentuk bukit pasir. Dengan demikian, maka batu ini tidak mungkin diterbangkan oleh angin, kecuali dibawa oleh manusia.

Alat-alat pelandas ini ditemukan pada kedalaman yang bervariasi. yaitu mulai dari $40 \mathrm{~cm}, 90--100 \mathrm{~cm}$, dan $250 \mathrm{~cm}$, yang bersesuaian dengan lapisan budaya-4, lapisan budaya-3, dan lapisan budaya-2. Di lapisan budaya-4, lapisan budaya-3, dan lapisan budaya-2 alat pelandas mempunyai korelasi temuan yang sama dengan alat penggosok, antara lain gerabah, keramik asing, rangka manusia, tulang hewan, artefak logam, dan temuan bukan artefak.

\subsection{Alat Pemukul (Paddle)}

Alat ini dibuat dari batu andesit, sedangkan bahan dari granit lebih sedikit. Alat pemukul ini berbentuk bulat telur yang bahannya diambil dari batu kali, sedangkan sebagian kecil dibuat dari pecahan alat batu lain yang telah rusak (lihat foto), mendekati bentuk trapesium dan bentuk-bentuk yang merupakan bagian alat aslinya. Ukuran alat pemukul berbentuk bulattelur yang paling besar berukuran $15 \times 11 \times$ $4,5 \mathrm{~cm}$, sedangkan alat pemukul yang dibuat dari pecahan alat lain berukuran $9 \times 7 \times 2,5 \mathrm{~cm}$.

Alat pemukul dari batu kali, ditandai oleh adanya kerusakan di tandai oleh kerusakan di bagian tepiannya yang digunakan untuk memukul benda keras. Selain itu, alat pemukul yang digunakan sebagai alat pemukul benda lunak yang masih basah. meninggalkan bekas pada salah satu permukaannya berpa bekas cairan. Sementara itu, alat pemukul yang dibuat dari pecahan bekas alat batu digunakan sebagai alat pemukul benda keras, sehingga meninggalkan bekasbekas kerusakan pada salah satu sisinya.

Alat-alat tersebut ditemukan pada beberapa tingkat kedalaman yaitu mulai dari $30 \mathrm{~cm}, 50 \mathrm{~cm}, 90 \mathrm{~cm}, 130 \mathrm{~cm}, 140 \mathrm{~cm}, 170 \mathrm{~cm}$, dan $290 \mathrm{~cm}$. Temuan alat pemukul itu terdapat pada kedalaman $30 \mathrm{~cm}$ dapat disejajarkan dengan lapisan budaya-4, kedalaman $50-90 \mathrm{~cm}$ 
dapat disejajarkan dengan lapisan budaya-3, kedalaman 130--170 cm dalam lapisan budaya-2, dan kedalaman $290 \mathrm{~cm}$ terdapat dalam lapisan budaya-1. Alat pemukul yang ditemukan pada lapisan budaya4. lapisan budaya-3, dan lapisan budaya-2 mempunyai korelasi temuan sama dengan alat batu yang telah diuraikan sebelumnya, sedangkan pada lapisan budaya- 1 berkorelasi dengan temuan yang sama juga tetapi teknik pembuatannya tampak lebih sederhana.

\section{Diskusi}

Situs Gunungwingko diketahui berasal dari masa perundagian seperti halnya situs-situs permukiman lain di pantai selatan Jawa (Goenadi Nh., 1996). Sementara itu, berdasarkan salah satu karakter situsnya, Gunungwingko termasuk dalam situs penguburan dan situs upacara (Goenadi Nh., 1970; 1974). Berdasarkan hal tersebut, maka fungsi temuan, baik artefak maupun bukan artefak, berkaitan dengan fungsi situs tersebut.

Temuan artefak dan bukan artefak apa pun tidak dapat dipisahkan dari lapisan budaya tempat temuan tersebut berada. Lapisan budaya yang berada di bawah dan lapisan budaya di atasnya, terbentuk dalam waktu yang tidak bersamaan, sehingga lapisan budaya ini pun dapat disejajarkan dengan hukum superposisi yang telah ditemukan oleh Nicoli Stetonis, seorang ahli geologi Italia pada tahun 1667. Hukum superposisi menjelaskan bahwa lapisan sedimen paling bawah terbentuk lebih tua daripada lapisan sedimen di atasnya, sebelum sedimen itu terubahkan oleh proses struktur geologi seperti lipatan, atau pun intrusi magma yang menyusup di antara sedimen tersebut (W.J. Fritz dan J.N. Moore, 1988:4).

Sehubungan dengan hal itu, tampak bahwa dari hasil analisis $\mathrm{C}_{14}$ di Amerika dan Groningen serta hasil analisis pertanggalan relatif dapat diketahui bahwa lapisan budaya-1 berasal dari 2000 tahun yang lampau", lapisan budaya-2 berasal dari 1400 tahun lyabg lampau, lapisan budaya-3 900 tahun, lapisan budaya-4 dari 250 tahun yang lalu. ${ }^{4}$ Berdasarkan hal tersebut, maka pemakaian alat batu semu di situs ini telah diketahui sejak 2000 tahun yang lalu sampai beberapa ratus tahun yang silam.

2 Hasil analisis C 14 dari Laboratorium Centum voor Isofopen Onderzoek di Groningen dengan No. sampel GrN-15908.

3 Laboratorium Center of Applied Isotope Studies di Amerika Serikat dengan No. sampel UGA-S3

4 Idem catatan no 2 
Penggunaan alat batu semu, atau alat semu dari jenis bahan yang lain, merupakan hasil imposisi yang bahannya telah disediakan oleh lingkungan alam di sekitarnya. Dengan demikian, alat ini pada mulanya tidak dapat dikenali sebagai alat, karena dianggap sebagai batu biasa yang tidak berguna. Sehubungan dengan itu, maka temuan alat semu ini perlu diwaspadai karena alat tersebut tidak memiliki ciriciri teknologi kecuali bekas-bekas pemakaian sehingga sukar dikenali ciri kealatannya

Alat batu semu yang ditemukan di Situs Gunungwingko telah mengalami perubahan fungsi. Berdasarkan konteks temuannya alat batu semu ini mempunyai fungsi seremonial sesuai dengan fungsi situs tersebut. Sebelum itu, alat ini digunakan untuk kepentingan praktis dalam kehidupan sehari-hari. Perubahan fungsi praktis menjadi fungsi seremonial merupakan hal yang umum, tidak hanya alat batu semu melainkan alat-alat lain misalnya gerabah. Gerabah yang digunakan sebagai bekal kujur, pada umumnya berasal dari gerabah yang digunakan sebagai keperluan sehari-hari (Weinberg, 1965) Dengan demikian, alat batu semu ini pun sebelumnya digunakan sebagai alat untuk mencukupi keperluan sehari-hari dan setelah pemilik atau anggota keluarga meninggal kemudian disertakan sebagai bekal kubur atau alat upacara lainnya.

Transformasi fungsi terjadi karena erat kaitannya dengan upacara pada waktu. Si Mati biasanya dibekali bermacam-macam barang keperluan sehari-hari seperti perhiasan, periuk, dasn barang-barang lain yang dikubur bersama-sama dengan maksud agar perjalanan $\mathbf{S i}$ Mati ke dunia awwah dan kehidupan selanjutnya akan terjamin sebaikbaiknya (Soejono, 1984). Demikian pula, penyertaan alat batu semu sebagai bekal kubur, sehingga alat tersebut mengalami transformasi fungsi dari fungsi praktis menjadi fungsi religis

Berdasarkan uraian mengenai fungsi alat batu di atas, dapat diperoleh beberapa gambaran tentang masyarakat pendukungnya. Dari fungsi seremonial dapat diketahui adanya suatu kebiasaan menyerta kan alat batu semu sebagai alat upacara dalam hubungannya dengan penguburan. Sémentara itu, dari fungsi praktis dapat memberi gambaran tentang aktivitas kehidupan sehari-hari masyarakat sesuai dengan fungsi alat batu tersebut. Di sisi lain, alat batu semu itu, dapat memberikan informasi, bahwa di Situs Gunungwingko teknologi alat batu belum dikuasai. Selain faktor ketrampilan, faktor lingkungan juga tidak mendukung terciptanya teknologi tersebut, seperti konsep ekologi budaya yang dikemukakan oleh J. H. Steward (1968) 


\section{Kesimpulan}

Berdasarkan uraian sebelumnya, dapat diperoleh gambaran bahwa alat batu semu Situs Gunungwingko, mempunyai fungsi seremonial yang digunakan sebagai sebagai bekal kubur atau alat upacara yang ada hubungan dengan penguburan. Selain fungsi seremonial, sebelumnya alat batu semu ini digunakan sebagai alat untuk keperluan sehari- hari. Penggunaan alat batu semu sebagai alat praktis disebabkan oleh penguasaan teknologi litik kurang memadai. Selain itu, lingkungan di sekitarnya tidak menyediakan bahan baku untuk pembuatan alat batu yang dilakukan dengan teknologi litik tertentu. Dengan demikian, dua hal penting yang tidak mendukung yaitu penguasaan teknologi dan lingkungan, menyebabkan masyarakat Gunungwingko masa lampau tidak mengenal alat batu yang dibuat dengan proses teknologi tertentu. Untuk mencukupi keperluan ini mungkin mereka mendatangkan alat batu dari daerah lain.

Keberadaan alat batu semu di Situs Gunungwingko merupakan hasil pengamatan terhadap temuan yang semula tidak diperhitungkan sebagai alat. Hal demikian dapat terjadi pada jenis temuan lain terutama temuan yang tidak jelas bentuknya misalnya alat yang dibuat dari terakota bukan gerabah. Masalah semacam ini tidak terjadi di Situs Gunungwingko saja, tetapi dapat terjadi di beberapa situs lain. Oleh karena itu, dalam kesempatan ini dapat disarankan, agar diperlakukan setiap temuan, baik artefak maupun bukan artefak, dalam porsi yang sama, untuk dihindari "kebocoran" data yang dikumpulkan dari hasil ekskavasi.

\section{Kepustakaan}

Fritz, William J \& Johnnie N Moore. 1988. Basic of Phisical Stratigraphy and Sedimentology. John Wiley \& Sons Inc., New York.

Geenadi Nitihaminoto. 1970. Unsur-unsur Prehistorik pada Gerabah Gunung Wingko. Seminar Sejarah Nasional II. Yogyakarta

1974. Laporan Gunung Wingko Tahap I dan Tahap II Lembaga Purbakala \& Peninggalan Nasional, Kantor Cabang I Prambanan

1996. Situs-situs Perundagian di Pantai Selatan Jawa: Tinjauan atas Pola Permukimannya. Evaluasi Hasil Penelitian Arkeologi, Ujung Pandang 
Hodges, Henry. 1981. Artifacts. An Introduction to Early Matorials and Technology. John Baker, London.

Moore, W.G. 1981. The Penguin Dictionary of Geography. Penguin Books. New York.

Soejono, R.P., 1984. Jaman Prasejarah di Indonesia, dalam Marwadi

Djoenedi Poesponegoro dan Nugroho Notosusanto (ed.) Sejarah Nasional Indonesia I. PN. Balai Pustaka, Jakarta.

Steward, Julian H. 1968. The Concept and Method of Cultural Ecotogy. Dalam Morton H Fried (ed.) Reading in Amthropology Vol II Cultural Anthropology. Thoma Y Crowell Company, New York.

Weinberg,Saul S. 1965. Ceramic and the Supernatural: Cult and Burial Evidence in the Aegean World. Dalam Frederick R. Matson (ed.) Ceramics and Man. Aldine Publishing Company, Chicago.

Whittow, John B. 1984. Dictionary of Physical Geography. Penguin Books, Great Britain.

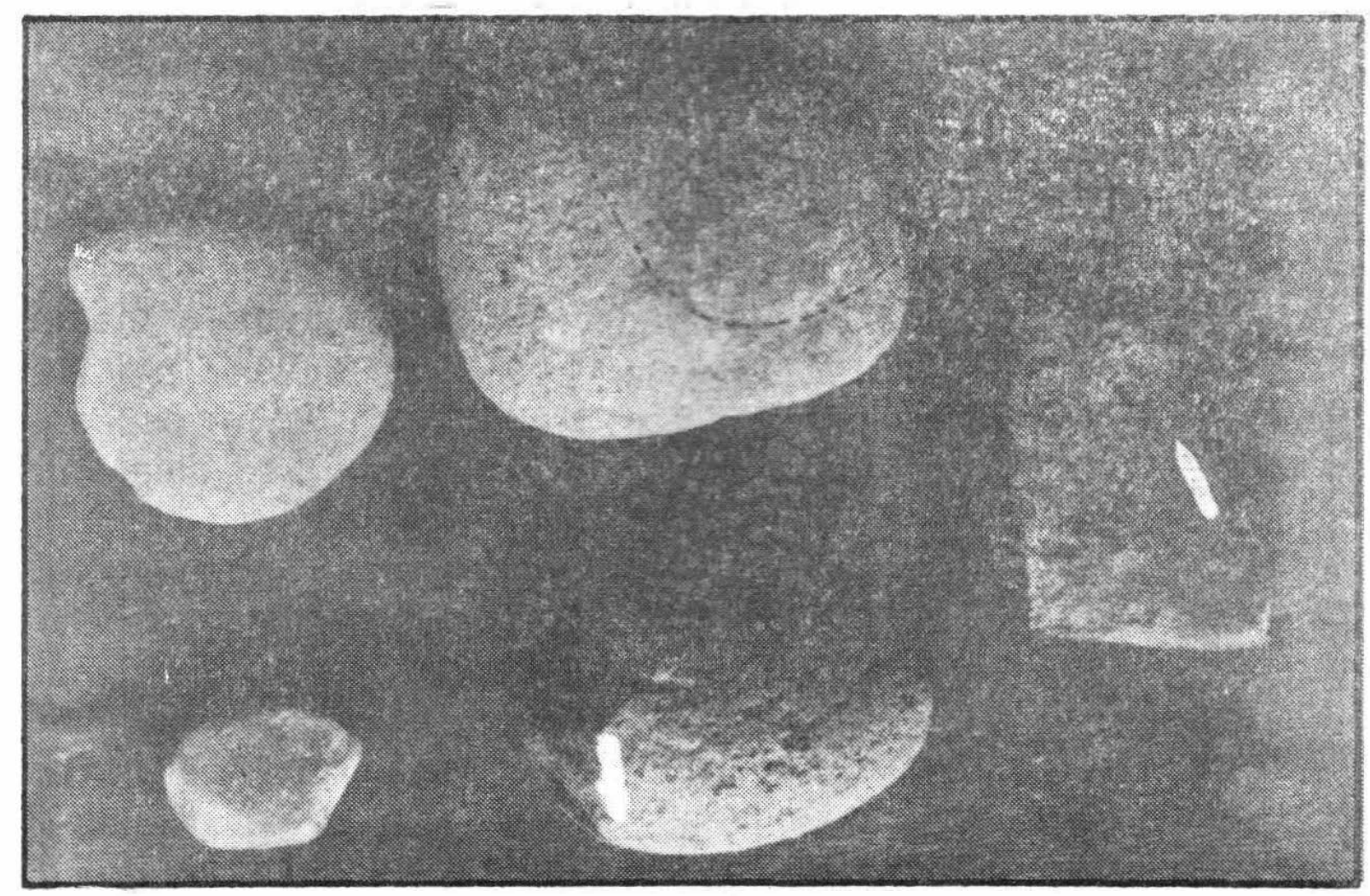

Keterangan:
1. Alat Penggosok
3. dan 5. Alat Pemukul
2. Alat Pelandas
4. Alat Pemukul benda lunak. 